\title{
Reactions to Crime as a Hierarchy Regulating Strategy: The Moderating Role of Social Dominance Orientation
}

\author{
Eva G. T. Green • Lotte Thomsen • Jim Sidanius • \\ Christian Staerklé • Polina Potanina
}

Published online: 23 October 2009

(C) Springer Science+Business Media, LLC 2009

\begin{abstract}
Across two studies, we demonstrated that support for group-based hierarchies differentially affects evaluation of ingroup and outgroup criminal offenders and that this effect generalizes to overall evaluations of their respective groups. Drawing on social dominance theory, our results show that differential judgments of national ingroup and immigrant outgroup offenders reflect hierarchy regulating strategies. Study $1(N=94)$ revealed that egalitarians (low on SDO) were more lenient toward outgroup offenders and their ethnic group (Arab immigrants) when compared to ingroup offenders and their national group (Swiss citizens). The opposite was true for social dominators (high on SDO). Study $2(N=88)$ replicated the results of Study 1 and further demonstrated that the socio-economic status of the perpetrator did not affect perpetrator group evaluations suggesting that the arbitrary sets of ethnicity or nationality, not education level and employment status, were the important cues for hierarchy-regulating judgments of criminal offenders.
\end{abstract}

Keywords Social dominance $\cdot$ Hierarchy regulation $\cdot$ Crime $\cdot$ Ethnic minorities

E. G. T. Green $(\bowtie)$ C. Staerklé

Institute of Social Sciences, Faculty of Social and Political Sciences, University of Lausanne, Vidy

Building, 1015 Lausanne, Switzerland

e-mail: eva.green@unil.ch

L. Thomsen · J. Sidanius

Department of Psychology, Harvard University, Cambridge, MA, USA

L. Thomsen

University of Copenhagen, Copenhagen, Denmark

J. Sidanius

Department of African American Studies, Harvard University, Cambridge, MA, USA

P. Potanina

Department of Psychology, New York University, New York City, USA 
Ethnicity is an important factor both in the media portrayals of crime and in the legal system. In public debates and in news coverage, ethnic minority group members are depicted more often than majority group members as offenders, in particular for street crime such as theft, physical aggression, or homicide (Campbell, 1995; Dixon \& Linz, 2000; Mendelberg, 2001). Ethnic minorities and individuals of immigrant origin constitute a disproportionate part of prison inmates in the United States and other Western countries (Currie, 1998; Johnson, Farrell, \& Stoloff, 2000; Sidanius \& Pratto, 1999; Wacquant, 1999; Young, 1999), and a substantial amount of evidence indicates more unfavorable legal outcomes for members of ethnic minority groups in the U.S. justice system (e.g., Gross \& Mauro, 1984). In fact, even when controlling for other relevant factors such as the severity of the crime or prior convictions, subordinate minorities are disadvantaged when compared to the dominant majority through all stages of the criminal justice process, from the likelihood of arrest (e.g., Bourg \& Stock, 1994), through the severity of the sentence imposed (e.g., Baldus, Woodworth, Zuckerman, Weiner, \& Broffitt, 1998; see also Eberhardt, Davies, Purdie-Vaughns, \& Johnson, 2006), to the chances of early parole (e.g., Dunwoody \& Frank, 1994). Hence, the criminal justice system is a core social institution that systematically reproduces group-based hierarchy (Sidanius \& Pratto, 1999). Reflecting the asymmetrical treatment of ethnic or immigrant minorities within the criminal justice system, the national majority groups' severe reactions toward subordinate minority offenders and corresponding support for relatively harsh punishments have been explained by their prejudiced attitudes (e.g., Barkan \& Cohn, 1994; Green, Staerklé, \& Sears, 2006; Soss, Langbein, \& Metelko, 2003). For example, in the United States, Whites holding negative stereotypes of African Americans judge African American offenders more severely and approve of more punitive measures against AfricanAmerican outgroup than against White ingroup offenders (Bagby \& Rector, 1992; Peffley \& Hurwitz, 2002; Peffley, Hurwitz, \& Sniderman, 1997).

However, a substantial body of research has also evidenced an opposite phenomenon of stronger derogation of deviant or transgressing ingroup members when compared to outgroup members, in particular when transgressors undermine crucial ingroup norms and when the evaluators are highly identified with the ingroup (Marques, Abrams, Páez, \& Martinez-Taboada, 1998; Marques, Abrams, \& Serôdio, 2001; Marques, Robalo, \& Rocha, 1992; Marques \& Yzerbyt, 1988). The derogation and subsequent punishment of ingroup members, coined the "black sheep" effect, is argued to reflect the functional affirmation of ingroup norms to reestablish a positive social identity. The current article draws on social dominance theory to understand such opposing reactions (Sidanius \& Pratto, 1999). More specifically, we argue that differential judgment of ethnic ingroup and outgroup criminal offenders and their respective groups reflect hierarchy-regulating strategies, i.e., strategies aimed at either enhancing or attenuating existing status differences. ${ }^{1}$ The two studies presented in this article investigate the role of support

\footnotetext{
1 In this article, we refer to ethnic minority and immigrant groups interchangeably, as both are subordinate groups in the social hierarchy, and because we expect similar reactions toward these groups when judging crime.
} 
for group-based hierarchies on the evaluation of national ingroup and ethnicminority immigrant outgroup offenders and extended group evaluations in a European context.

\section{Hierarchy Regulation, Evaluation of Criminal Offenders and Member-to-Group Generalization}

The central objective of social dominance theory is to understand how and why human social systems tend to be organized as group-based hierarchies (Pratto, Sidanius, \& Levin, 2006; Sidanius \& Pratto, 1999). In stratified social systems, dominant groups enjoy a disproportionate share of resources, power, and positive social value when compared to subordinate groups. Both racism and "race-neutral" principles such as political conservatism provide moral and intellectual justification for maintaining and increasing levels of social inequality among social groups, thereby legitimizing the maintenance of structural group-based social hierarchies (e.g., Jost, Glaser, Kruglanski, \& Sulloway, 2003; Sidanius, Levin, Rabinowitz, \& Federico, 1999). Harsh punishment of ethnic minority or immigrant perpetrators is one strategy, among many others, of maintaining the existing hierarchical social order.

According to social dominance theory, the dominant ingroup members' differential appraisal of ethnic ingroup and minority outgroup offenders is ultimately driven by individual desires to enforce the existing societal hierarchy, indexed by social dominance orientation (SDO, see Pratto, Sidanius, Stallworth, \& Malle, 1994). SDO expresses the desire for group-based dominance and opposition to social equality, and has been found to be among the most important motives underlying prejudice and discrimination against ethnic minorities (e.g., Altemeyer, 1998; McFarland \& Adelson, 1996). Social dominance is also associated with support for harsh criminal sanctions, such as support for capital punishment and torture, and these relationships are mediated by deterrence and retribution beliefs (Sidanius, Mitchell, Haley, \& Navarrete, 2006). A recent experimental study revealed that SDO predicted acceptance of the use of deadly force among police officers (Perkins \& Bourgeois, 2006). Moreover, police officers, holding hierarchyenhancing roles in society, score higher on SDO than public defenders, holding hierarchy-attenuating roles in society (Sidanius, Liu, Shaw, \& Pratto, 1994).

In this article, we argue that the so-called black sheep effect (i.e., the greater derogation of ingroup than outgroup deviants) is also driven by hierarchy-regulation motives. We examine the extent to which exposure to criminal acts committed by members of the national ingroup and of an ethnic-minority immigrant outgroup provides an occasion for regulating the hierarchical relations between ethnic and social groups. Consistent with our hierarchy-regulation argument, Kemmelmeier (2005) demonstrated in a mock-jury study that individuals who were high on SDO were more favorable toward White than Black offenders in terms of guilty verdicts and sentence recommendations, whereas the opposite pattern was true for individuals who were low on SDO (see also Mendoza, Páez, Marques, Techio, \& Espinosa, 2005). 
We go a step further and examine the extent to which harsh or lenient evaluation of criminal acts perpetrated by individual ethnic-minority members extend to perceptions of the entire outgroup through a process of member-to-group generalization: When delinquent behavior perpetrated by minority members matches negative stereotypes associated with that group, people easily generalize the negative appraisals of the individual perpetrator to the entire outgroup (Wilder, Simon, \& Faith, 1996). Thus, SDO should not only predict harsh judgments of an ethnic minority offender, but also harsh judgments of the entire ethnic-minority group in question. In this way, the target-to-group generalization effect contributes to the study of the continuous reproduction and justification of group hierarchy (Jost, Banaji, \& Nosek, 2004; Pratto et al., 2006; Sidanius \& Pratto, 1999).

Because derogating the entire outgroup is a hierarchy-enhancing strategy of advantaged groups, social dominators should downgrade outgroup criminals and, by extension, their ethnic or national groups, relative to ingroup criminals. From the dominant majority's perspective, an offending subordinate minority outgroup member provides a legitimate reason for derogating the entire ethnic outgroup. The outgroup as a whole, the offender and the crime should be judged more negatively and the act should be perceived as a more prototypical act of an outgroup member than an ingroup member. In contrast, for egalitarians, i.e., individuals who are low in SDO and for whom hierarchy attenuation is a key motivation, we expect the opposite pattern. Individuals low in SDO should be motivated to attenuate or even abolish inequalities between groups. This motivation is thus expected to lead to more lenient attitudes toward subordinate outgroup offenders, and their entire ethnic group, when compared to majority ingroup offenders and their group. This pattern should be more likely to occur in contexts in which the outgroup is stigmatized and occupies a low social status position, to the extent that differential crime judgments may contribute to justifying inequality between minorities and majorities.

\section{The Present Research}

Whereas research on ethnic bias within the criminal justice system has been carried out primarily in the United States, the present two studies investigate the role of support for group-based hierarchy on the evaluation of ingroup and outgroup criminal offenders in a European context in which ethnic bias should manifest itself in the derogation of offenders of immigrant descent (e.g., Dambrun, 2007). In both studies, an Arab immigrant male was depicted as the ethnic outgroup offender. Arabs were chosen as a target group, because in Switzerland (where the studies were carried out) they represent a relatively clearly defined, though small immigrant group, and because there was little normative pressure for non-discrimination of Arabs at the time of the studies (e.g., Echebarria Echabe \& Fernandez Guede, 2007; Strabac \& Listhaug, 2008; see also Falomir-Pichastor, Muñoz-Rojas, Invernizzi, \& Mugny 2004). Study 1 examines the predicted hierarchy-regulating processes associated with crime judgments using different types of crime, to ensure that the expected hierarchy-regulating effects could not be due to a particular type of crime or to different levels of perceived gravity of the crimes. Because ethnic-minority 
immigrants often suffer from relatively low social status (e.g., African or Arab immigrants), Study 2, in turn, addresses the question whether the socio-economic status of the offender interacts with the predicted hierarchy-regulating processes associated with criminal judgments.

\section{Study 1}

This study examines the generalization of hierarchy-regulating processes across different types of crime. In order to develop plausible scenarios, we wanted to make sure that the two types of crimes were both stereotypically associated with the Arab perpetrator outgroup. Based on longstanding images of "Orientals" and "Arabs" in Western thinking, which sees Arab males as cruel and deceptive on the one hand and as engaging in immoral sexual conduct on the other (Said, 1978; see also Oswald, 2005; Persson \& Musher-Eizenman, 2005; Shaheen, 2003), we used treason and rape as the two types of crimes. In our scenarios, treason refers to a politically motivated crime which is carried out in the name of one's (national) group, whereas rape is a sexually motivated, interpersonal crime independent of political motives (however, see Brownmiller, 1975). We operationalized a mild form of political crime, treason, instead of, for example, a terrorist attack to make it conceivable that both a national ingroup and an ethnic outgroup member could commit it. To examine whether the judgment of the offender generalizes to the entire national or ethnic group, group evaluation measures were included in the study. SDO was expected to moderate crime judgments such that individuals who are high on SDO are harsher toward the outgroup, whereas individuals low on SDO are harsher toward the ingroup (yielding the black sheep effect).

\section{Method}

\section{Participants}

Ninety-four social sciences students at a Swiss university participated (73\% females; mean age 22.5 years). Eleven participants did not have Swiss nationality and were excluded from further analyses. Participants filled out the questionnaire in French during a mass lecture. Participation was voluntary and three small cash prizes were drawn in a lottery as compensation.

\section{Procedure and Design}

An assessment of SDO was followed by a crime scenario in which the ethnicity of the offender was manipulated. In the dominant ingroup condition, the offender was a 23-year-old Swiss male (David), whereas in the subordinate outgroup condition the offender was a 23-year-old Arab immigrant (Abdul). Participants read either a scenario in which the offender attacks a woman of his age after walking her home from a party, or a scenario in which the offender has contacts with a fundamentalist anti-government group and provides them classified government documents 
concerning an investigation. In order to make the second scenario plausible, the offender was described in both scenarios as a janitor working in a government office. The offender received a one-year prison sentence for attempted rape or treason, respectively. After reading the scenario, participants evaluated the group, the offender and the crime. Participants were debriefed upon finishing.

\section{Measures}

Social Dominance Orientation Participants completed a 16-item SDO scale varying from 1 (strongly disagree) to 7 (strongly agree). A social dominance score was computed $(\alpha=.88)$. Overall, participants were low on SDO $(M=1.90$, $S D=.75)^{2}$

Group Evaluation Group negativity (Swiss or Arab immigrants in general) was assessed with one item varying from 1 (very good) to 7 (very bad) $(M=3.46$, $S D=1.26)$. Group prototypicality concerns the extent to which the offender was perceived a prototypical member of his ethnic group and was also assessed $(1=$ not at all typical, $7=$ very typical; $M=3.17, S D=1.39$ ).

Offender Extremism The participants were asked to judge the level of extremism of the offender on a seven-point scale. Four items assessed the extent to which the offender was perceived as extremist (extremist, fundamentalist religious, intolerant, irrational; $\alpha=.79 ; M=4.56, S D=1.09$ ).

Offence Seriousness One item indicated how serious the participants judged the offence $(1=$ not at all serious, $7=$ very serious; $M=4.87, S D=1.43)$.

National Identification This construct was assessed by a three-item scale asking: (a) How strongly do you identify with other people of your nationality, (b) how close do you feel to other people of your nationality, and (c) how often do you think about yourself in terms of your nationality $(1=$ not at all, $7=$ very strongly/closeloften; $\alpha=.86 ; M=3.73, S D=1.26$ ). This variable was assessed before the experimental manipulation. In complementary analyses, we examined whether national identification would play a role, because the black sheep effect has often been found among highly identifying group members.

\section{Results}

Regression analyses were conducted on group appraisals (group negativity, offender prototypicality), perceived offender extremity and perceived seriousness of offence evaluations as outcome variables. The centered SDO scores, ethnicity of offender $(-0.5=$ Arab, $0.5=$ Swiss $)$, crime type $(-0.5=$ rape, $0.5=$ treason $)$, and the SDO $\times$ ethnicity of offender interaction term were used as predictors. The

\footnotetext{
${ }^{2}$ An exploration of distributions revealed that SDO was positively skewed and was therefore log-transformed. Analyses are on the original score since the results were identical.
} 
interaction term tested our main prediction concerning the moderating role of SDO on ethnicity of offender effects. In preliminary analyses, crime type $\times$ SDO, crime type $\times$ ethnicity, and crime type $\times$ ethnicity $\times$ SDO interaction terms were entered in the model. Since no predictions were made for these interactions, and since none of them revealed any significant effects or modified any of the presented effects, they were dropped from the further analyses. Table 1 summarizes the findings. Finally, supplementary analyses including the national identification measure and related interactions were carried out.

\section{Group Evaluation}

The overall evaluation of the offender group and prototypicality of the offender were predicted by SDO, such that SDO predicted greater unfavorable overall impression of the offender group $(b=.52, S E=.16, p=.001)$ and considering the offender as more typical of his group $(b=.69, S E=.19, p=.001)$. Both main effects were qualified by a SDO by ethnicity of offender interaction $(b=-1.55$, $S E=.31, p=.001$ and $b=-.94, S E=.38, p=.02$, respectively). Simple slope analyses (see Fig. 1a) revealed that social dominance predicted more negative group perceptions of Arabs $(b=1.30, S E=.23, p=.001)$, but did not predict negative group perceptions of the Swiss $(b=-.25, S E=.22, p=.26)$. Differences in slope points were calculated at 1 SD above and below mean SDO (Aiken \& West, 1991) to further assess the nature of the interaction term. Social dominators $(+1 S D)$ had a more negative impression of the Arab outgroup $\left(M_{\text {est }}=4.27\right)$ than of the Swiss ingroup $\left(M_{\mathrm{est}}=3.37 ; t(79)=2.71, p=.01\right)$. In contrast, egalitarians $(-1 S D)$ had a more negative impression of their Swiss ingroup $\left(M_{\text {est }}=3.76\right)$ than of the Arab outgroup $\left(M_{\text {est }}=2.33 ; t(79)=-4.22, p=.001\right)$.

A similar pattern emerged for group prototypicality assessments (Fig. 2a). Simple slope analyses indicated that social dominance was positively related to perceiving the Arab perpetrator as typically Arab $(b=1.16, S E=.27, p=.001)$, but social dominance was not related to perceiving the Swiss perpetrator as typically Swiss $(b=.22, S E=.27, p=.43$ ). The comparison of slope points revealed that egalitarians perceived the offender as more typical of his Swiss ingroup $\left(M_{\mathrm{est}}=3.18\right)$ than of the Arab outgroup $\left(M_{\mathrm{est}}=2.06 ; t(79)=-4.22, p<.001\right)$, but for social dominators the typicality evaluations of the Swiss $\left(M_{\mathrm{est}}=3.51\right)$ and the Arab target $\left(M_{\text {est }}=3.81\right)$ did not differ $(t(79)=.80, p=.43)$.

Crime type did not affect the overall evaluation of the offender group or perceived prototypicality of the offender.

\section{Offender and Offence Evaluation}

The Swiss offender was rated as more extreme than the Arab immigrant offender $(b=.55, S E=.23, p=.02)$. Importantly, the effect of ethnicity on extremism judgments was informed by a social dominance $\times$ ethnicity interaction $(b=-.78$, $S E=.30, p=.01$; an interaction pattern similar to Fig. 1a). Simple slope analyses demonstrated that SDO was related positively to extremism evaluations $(b=.56$, $\mathrm{SE}=.22, p=.01)$ in the Arab perpetrator condition. In the Swiss perpetrator 


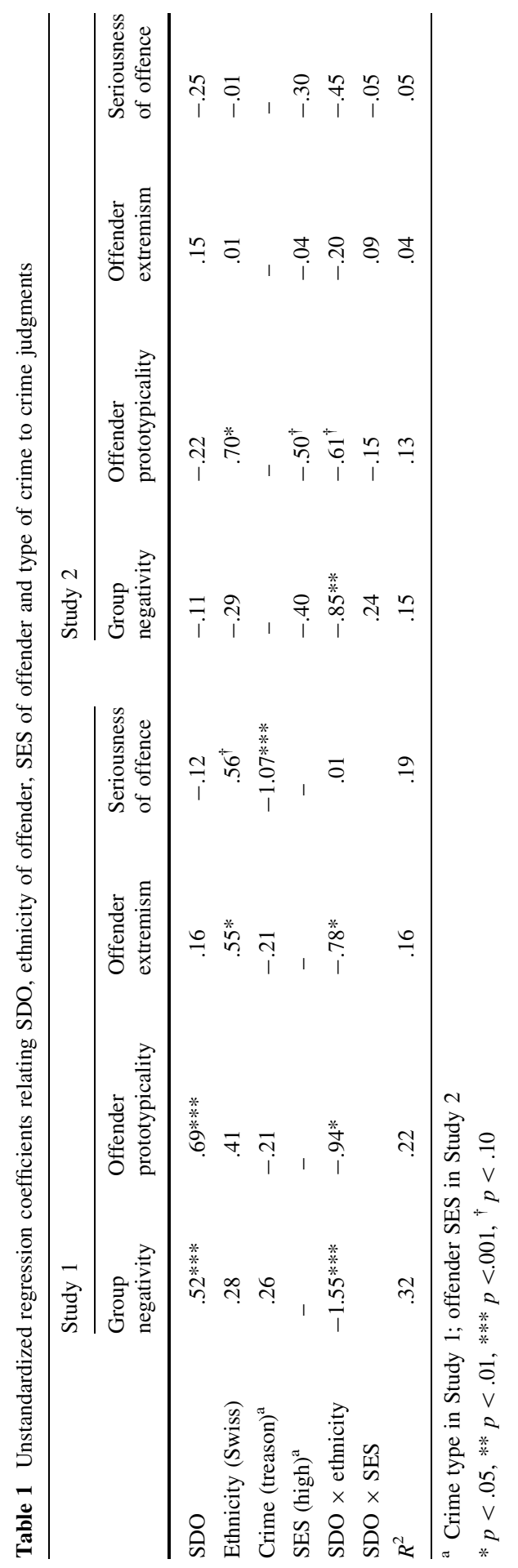



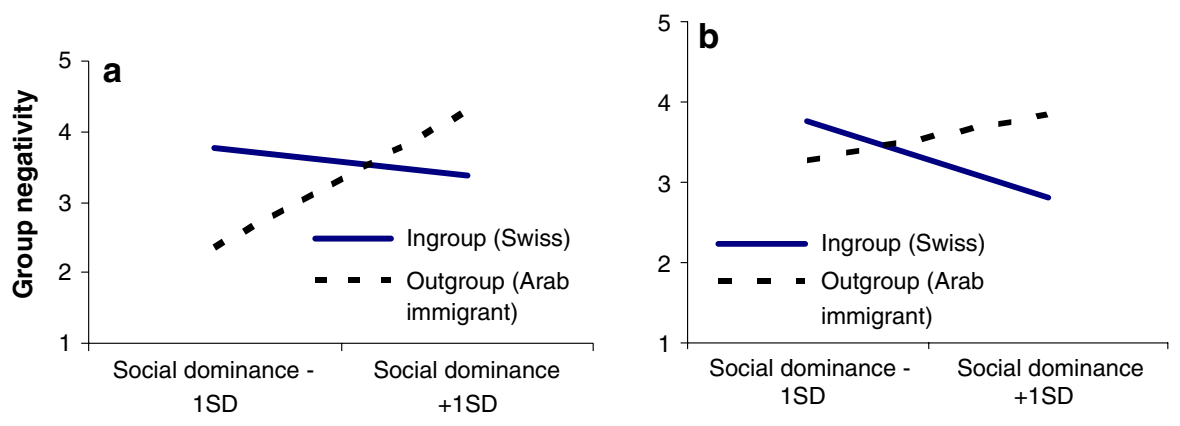

Fig. 1 Perceptions of group negativity as a function of offender ethnicity and participant social dominance orientation. Study 1 (a) and Study 2 (b)
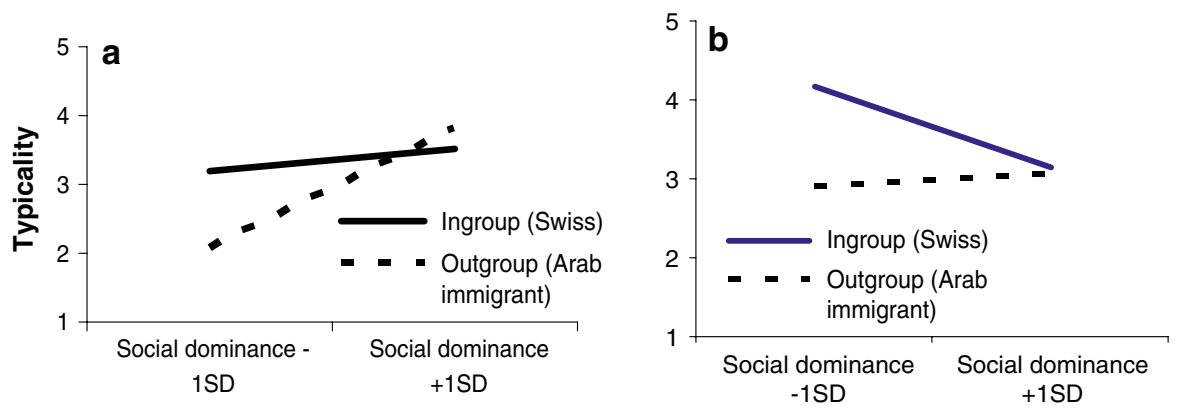

Fig. 2 Perceptions of prototypicality as a function of offender ethnicity and participant social dominance orientation. Study 1 (a) and Study 2 (b)

condition, the relationship was negative $(b=-.22, S E=.21, p=.29)$, though not significantly so. The comparisons of slope points demonstrated that egalitarians perceived the Arab offender $\left(M_{\text {est }}=3.84\right)$ as less extreme than the Swiss offender $\left(M_{\mathrm{est}}=4.99 ; t(79)=-3.56, p<.001\right)$, suggesting that a relative devaluation of an ingroup perpetrator is driven by hierarchy-attenuating concerns. Social dominators' extremism evaluations of the Swiss $\left(M_{\text {est }}=4.68\right)$ and the Arab target $\left(M_{\text {est }}=4.65\right)$ did not differ $(t(79)=.13, p=.90)$. No other effects were significant for extremism judgments.

The offence was perceived as marginally more serious when the offender was Swiss than when the perpetrator was an Arab immigrant $(b=.56, S E=.29$, $p=.06)$. Type of crime influenced perceived gravity of the offence; the attempted rape was perceived as more serious than attempted treason $(b=-1.07, S E=.29$, $p<.001)$. Ethnicity and SDO did not interact $(b=.01, S E=.39, p=.99)$.

\section{Complementary Analyses with National Identification}

Research has shown that highly identified group members react more negatively to a deviant ingroup member than to a deviant outgroup member (e.g., Marques et al., 1998). To demonstrate that SDO explains differential crime judgments, additional 
analyses were carried out by including the standardized national identification measure, the national identification $\times$ offender ethnicity interaction, and the SDO $\times$ national identification $\times$ offender ethnicity interaction in our main model. All possible lower-level interactions were included in the model, but we only report the above-mentioned interactions. The national identification $\times$ offender ethnicity interaction did not reach significance for group, offender or offence evaluations $(b=-.18, S E=.21, p=.39$ for group negativity; $b=-.43, S E=.26, p=.10$ for offender prototypicality; $b=-.31, S E=.21, p=.14$ for offender extremism; $b=-.03, S E=.28, p=.92$ for perceived seriousness of the crime). Moreover, the SDO $\times$ national identification $\times$ offender ethnicity interaction was not statistically significant for any of the evaluations $(b=-.11, S E=.26, p=.67$ for group negativity; $b=-.09, S E=.30, p=.76$ for offender prototypicality; $b=.16$, $S E=.25, p=.54$ for offender extremism; $b=-.06, S E=.33, p=.86$ for perceived seriousness of the crime). One national identification main effect was revealed. High identification was related to low overall group negativity evaluations $(b=-.23, S E=.11, p=.03)$. The crucial SDO $\times$ ethnicity of offender interaction, i.e., the predicted hierarchy-regulation effect, remained similar in all models, though it was no longer statistically significant for offender extremism evaluations.

\section{Discussion}

Study 1 demonstrated that group and offender evaluations varied as a function of SDO, thereby providing evidence for the hierarchy-enhancing motivations of social dominators and the hierarchy-attenuating motivations of egalitarians when evaluating minority outgroup perpetrators. When participants judged an Arab immigrant offender, SDO positively predicted the perceptions of outgroup negativity, prototypicality of the offender, and offender extremity assessments, but not perceptions of offence gravity. Yet, SDO was unrelated to these assessments when participants were presented with a Swiss ingroup offender. Nevertheless, as expected, egalitarians were stricter toward the dominant ingroup than toward the subordinate outgroup. For individuals high in SDO, the crossover interactions depicted in the two figures revealed substantial differences in assessments between the Arab and the Swiss offender only in terms of group negativity. This is presumably due to the rather low SDO levels in the sample: At the highest social dominance levels (i.e., $3 S D$ above the mean), group negativity, offender prototypicality, and extremism were significantly greater for the Arab offender when compared to the Swiss offender. Type of crime did not affect group or offender assessments, nor did it interact with the other predictor variables, providing evidence for the generalization of the hierarchy-regulation effect. Nevertheless, attempted rape was judged to be a more serious crime than attempted treason. Moreover, the complementary analyses showed that hierarchy-regulation motives, assessed with SDO, operate independently of national identification.

However, it remains unclear whether the socio-economic status of the perpetrator plays a role in these assessments, since the offender was always depicted as having low-status employment. To the extent that Arab immigrants make up a stigmatized outgroup which is most often assigned to low-status positions in society, in Study 2, 
we aim to clarify whether it is the offenders' position in the social hierarchy or the asymmetrical status of ethnic ingroups and outgroups that drives the hierarchyregulating motivations.

\section{Study 2}

In this study, we explore whether the low status associated with the ethnic group yields the same hierarchy-regulating effects as low socio-economic status as such. Insofar as socio-economic status (SES) and ethnicity are both conceived as socially constructed arbitrary-sets of hierarchical systems in social dominance theory (Sidanius \& Pratto, 1999), the hierarchy-regulation motives should indeed be similar. If this assumption is correct, egalitarians, motivated by hierarchy attenuation, should be more lenient toward both low-status and ethnic-minority outgroup offenders and more strict toward high-status and ingroup offenders. Social dominators, motivated by hierarchy maintenance, in contrast, should be more lenient toward both high-status and ingroup offenders, and harsher toward lowstatus and ethnic-minority outgroup offenders. As SDO should relate similarly to attitudes toward ethnic minorities and low-status groups, the derogation of an ethnic-minority offender with low social status should be greater than that of the ethnic-minority criminal with high social status, i.e., the high socio-economic status should partially counteract the negative associations related to the ethnic group. The hierarchy-regulation conjecture thus suggests a motivated upgrading of a double high-status (ethnic and SES) target and a downgrading of a double low-status target among social dominators and the opposite pattern among egalitarians.

Manipulating both perpetrator ethnicity and SES, this study investigates whether SES, in addition to ethnicity of the perpetrator, affects group and offender evaluations. The respondents of the current study have a double high status as members of the dominant national group and as enjoying relatively high standing in Swiss society as university students. ${ }^{3}$

\section{Method}

\section{Participants}

Eighty-eight Swiss first year psychology students (83\% females; mean age 22 years) filled out the questionnaire in French during a mass lecture. Participation was voluntary.

\section{Procedure and Design}

An assessment of SDO was followed by the attempted rape scenario of Study 1 in which the ethnicity of the offender was manipulated. In the ingroup condition, the

\footnotetext{
${ }^{3}$ University students have high status in Swiss society, since only $29 \%$ of the population between 25 and 64 years have a tertiary-level education (OECD, 2007).
} 
offender was a 27-year-old Swiss male (David), whereas in the outgroup condition the offender was a 27-year-old Arab immigrant (Abdul). Social status of the offender was also manipulated, whereas type of crime was kept constant (rape). David and Abdul were either depicted as having no education and being unemployed (low SES) or as having a university degree and being employed by a company (high SES). As in Study 1, participants judged the ethnic or national group of the perpetrator, the perpetrator of the crime, and the crime itself. After completing the questionnaire, each participant was given a written debriefing as well as the option to discuss the aims of the study with questionnaire administrators.

\section{Measures}

All measures were identical to those used in Study 1: SDO $(\alpha=.87, M=2.50$, $S D=.85)$, group negativity $(M=3.40, S D=1.20)$, offender prototypicality $(M=3.22, S D=1.38)$, offender extremism $(\alpha=.65 ; M=4.79, S D=.82)$, and seriousness of offence $(M=3.24, S D=1.52)$. Again, national identification was assessed $(\alpha=.89 ; M=3.80, S D=1.31)$ to ensure that the predicted effects of SDO occur even when controlling for group identification.

As a manipulation check on the main effects, participants indicated the extent to which the perpetrator on the one hand and his ethnic or national group on the other had a favorable position in Swiss society $(1=$ unfavorable, $7=$ favorable $)$.

\section{Results}

\section{Manipulation Check}

Two 2 (Swiss vs. Arab offender ethnicity) $\times 2$ (high vs. low offender SES) ANOVAs were conducted on the perceived position of the offender and his group in the social hierarchy. A main effect for offender ethnicity revealed that the Swiss perpetrator $(M=4.18, S D=1.97)$ was perceived to have a more favorable position in the social hierarchy than the Arab perpetrator $(M=3.35, S D=1.54)$, $F(1,84)=5.73, p=.02$. The status main effect showed that the high SES offender $(M=4.61, S D=1.74)$ was perceived to hold a better position in society than the low SES offender $(M=2.74, S D=1.23), F(1,84)=37.4, p<.001$.

The offender ethnicity main effect for perceived group status indicated that overall Swiss $(M=5.23, S D=1.71)$ were perceived as holding a better position in Swiss society than Arabs $(M=2.92, S D=1.27 ; F(1,84)=49.11, p<.001)$. No other main effects or interactions were significant.

\section{Group, Offender, and Offence Evaluations}

Regression analyses were carried out on perceived group negativity, offender prototypicality, offender extremity, and seriousness of offence evaluations as outcome variables. The centered SDO scores, ethnicity of offender $(-0.5=$ Arab, $0.5=$ Swiss $)$, offender SES $(-0.5=$ low, $0.5=$ high $)$, the SDO $\times$ offender ethnicity and SDO $\times$ offender SES interaction terms were used as predictors. 
The interactions tested our main prediction concerning the moderating role of SDO. To gain statistical power, and since preliminary analyses did not reveal any significant effects, the offender SES $\times$ ethnicity, SDO $\times$ offender SES $\times$ ethnicity interaction terms were dropped. Table 1 summarizes the findings.

For the group negativity evaluation, no significant main effects of SDO, offender ethnicity, or offender SES were found. However, as in Study 1, a SDO $\times$ offender ethnicity interaction was found $(b=-.85, S E=.30, p=.01)$. In line with the moderation hypothesis (see Fig. 1b), simple slopes analyses demonstrated that SDO predicted negative group perception of Arabs $(b=.33, S E=.19, p=.09)$, whereas SDO significantly predicted positive group perception of the Swiss $(b=$ $-.56, S E=.23, p=.05)$. Differences in the slope points were calculated at $1 \mathrm{SD}$ above and below mean SDO. Social dominators $(+1 S D)$ had a less negative impression of the Swiss ingroup $\left(M_{\text {est }}=2.80\right)$ than of the Arab outgroup $\left(M_{\mathrm{est}}=3.85 ; t(82)=3.20, p=.002\right)$. Egalitarians $(-1 S D)$ had a less negative impression of the Arab outgroup $\left(M_{\text {est }}=3.25\right)$ than of the Swiss ingroup $\left(M_{\mathrm{est}}=3.75\right)$, but this difference was not statistically significant $(t(82)=-1.12$, $p=.27)$. Though the SDO $\times$ offender SES $(b=.24, S E=.30, p=.43)$ and $\mathrm{SDO} \times$ offender SES $\times$ offender ethnicity $(b=-.53, S E=.61, p=.38)$ interactions were not significant, regression equations for each experimental condition were specified and compared for social dominators and egalitarians to examine the polarization of double low or double high status perpetrator. As expected, social dominators had the most favorable overall group evaluation when presented with a high-status Swiss perpetrator $\left(M_{\text {est }}=2.67\right)$ and the least favorable overall group evaluation when presented with a low-status Arab perpetrator $\left(M_{\text {est }}=4.03\right)$, $F(1,79)=4.52, p=.04$. However, the overall group evaluation when presented with the high- or low-status Swiss perpetrator $\left(M_{\mathrm{est}}=2.67\right.$ and $M_{\mathrm{est}}=2.94$, respectively) did not differ. Moreover, both these group evaluations were more favorable than the overall group evaluation when presented with the high- or lowstatus Arab perpetrator $\left(M_{\text {est }}=3.75\right.$ and $M_{\text {est }}=4.03$, respectively $)$ that did not differ. Further analyses revealed that socio-economic status of the offender did not affect evaluations by egalitarians either.

Offender prototypicality was predicted by offender ethnicity $(b=.70$, $S E=.30, p=.02)$ and marginally by offender SES $(b=-.50, S E=.29$, $p=.09$ ). Swiss and low SES offenders were perceived as more typical Swiss and as more typical low SES, respectively, when compared to Arab and highstatus offenders. The SDO $\times$ ethnicity interaction revealed a marginal effect ( $b=-.61, S E=.35, p=.09$ ) (Fig. 2b). Simple slope analyses revealed that social dominance was negatively related to perceived prototypicality of the Swiss offender $(b=-.61, S E=.27, p=.03)$. The effect of SDO in the Arab condition was in the expected direction but did not reach significance $(b=.08$, $S E=.22, p=.73$ ). Comparisons of slope points further demonstrated that egalitarians perceived the Swiss offender as more typical of their Swiss ingroup $\left(M_{\text {est }}=4.16\right)$ than the Arab offender of the Arab outgroup $\left(M_{\text {est }}=2.91\right)$, $t(82)=-2.78, p=.01$, whereas for social dominators the typicality evaluations of the Swiss $\left(M_{\text {est }}=3.13\right)$ and the Arab target $\left(M_{\text {est }}=3.04\right)$ did not differ $(t(82)=-.07, p=.94)$. The SDO $\times$ offender SES interaction failed to reach 
significance and regressions, specified for each experimental condition, revealed that perpetrator SES did not affect prototypicality evaluations. SDO, offender ethnicity, and SES had no main or interactive effects on perceived offender extremism and on perceived offence seriousness.

\section{Complementary Analyses with National Identification}

Finally, we again wanted to show that SDO contributes, independently of national identification, to explain differential crime judgments. Additional analyses including national identification $\times$ ethnicity of offender and SDO $\times$ national identification $\times$ ethnicity of offender interactions were included in the model, along with other lower-level interactions. The national identification $\times$ ethnicity of offender interaction only predicted offender extremism $(b=-.36, S E=.15, p=.02)$, but the overall model was not significant, $F(8,78)=1.49, p=.18$. For the other measures, the national identification $\times$ ethnicity of offender interaction did not reach significance $(b=-.26, S E=.21, p=.22$ for group negativity; $b=.01$, $S E=.25, p=.95$ for offender prototypicality; $b=.40, S E=.25, p=.15$ for perceived seriousness of the crime). As in Study 1, the SDO $\times$ national identification $\times$ offender ethnicity interactions were not significant $(b=.20$, $S E=.24, p=.41$ for group negativity; $b=-.08, S E=.30, p=.78$ for offender prototypicality; $b=.15, S E=.17, p=.35$ for offender extremism; $b=-.12$, $S E=.32, p=.70$ for perceived seriousness of the crime). Most important, the SDO $\times$ offender ethnicity interaction, testing the predicted hierarchy-regulation effect, remained significant for both group judgments.

\section{Discussion}

Results of this study replicated, though less strongly, the findings of Study 1 showing that hierarchy-regulating motivations, indexed by SDO, moderate evaluations of national majority and ethnic minority offender groups. The prediction concerning the role of offender socio-economic status on evaluation received partial support. In line with the hierarchy-maintenance conjecture suggesting a motivated upgrading of double high-status (ethnic and SES) target and a downgrading of a double low-status target, the results indicated that social dominators provided the most positive group evaluations when presented with a high-status national ingroup offender and the most negative evaluations when presented with a low-status ethnic outgroup offender. However, both high- and low-status Swiss as well as high- and low-status Arabs were evaluated similarly. Socio-economic status did not affect egalitarians' group negativity evaluations.

\section{General Discussion}

The current research investigated differential judgments of ethnic and national ingroup and outgroup offenders and their respective groups as hierarchy-regulating strategies. The two studies provide support for the moderating role of attitudes 
toward social hierarchy on crime evaluations in intergroup contexts. In line with social dominance theory, Study 1 confirmed that SDO predicted negative appraisals toward the entire Arab outgroup to which the minority perpetrator belonged. Type of crime did not affect appraisals providing evidence for the generalization of the hierarchy-regulation effect. In both studies, but more strongly so in Study 2, the relationship between SDO and appraisal was reversed when the perpetrator was a Swiss citizen (i.e., an ingroup majority member). That is, egalitarians provided more lenient evaluations of the outgroup than the ingroup, whereas the opposite was true for social dominators. This pattern was the clearest in overall group negativity evaluations, highlighting the motivation to enhance or attenuate between-group dominance that we argue underlies hierarchy regulation.

Study 2 compared the effects of two types of status differences by investigating whether the hierarchy-regulating strategy revealed in the offender group evaluations was similar for socio-economic and ethnic-group status. The influence of socioeconomic status of offenders, as expected, did not override the moderating impact of SDO on effects of ethnicity. In this study, SDO was therefore more closely related to ethnic hierarchy than to a hierarchy based on education and employment status. Thus, hierarchy-regulation strategies are deployed to keep subordinate ethnic minority groups in "their place" even when individual SES is made salient. Though social class, like race or ethnicity, is a socially constructed arbitrary set of social hierarchies (Sidanius \& Pratto, 1999), perpetrator SES had little effect on group evaluations in this study, i.e., when ethnicity is salient, education level and employment status are less important cues for evaluating criminal offenders. We speculate that cultural context moderates this result: Ethnicity is a more compelling arbitrary set of domination in the individualistic and economically liberal Swiss context, where SES is likely to be perceived as the outcome of individual efforts rather than as the result of class-based hierarchy. This may not be the case in societies with a longstanding, salient, and impermeable social class or caste system where education and employment may be enough to trigger arbitrary set notions. Further studies are needed to examine whether ascribed versus achieved nature of social status play a role in hierarchy-regulating judgments of criminal offenders.

One could also argue that the sub-dimensions of the SDO construct, group-based dominance (GBD) and opposition to inequality (OEQ), might have differential effects on crime judgments. For example, Jost and Thompson (2000) found that GBD was more related to ethnocentrism than OEQ was, whereas OEQ was more related to economic system justification. Thus, regarding our study, GBD might be more sensitive to offender ethnicity and OEQ might be more sensitive to offender SES. But additional analyses, employing GBD and OEQ as separate predictors, did not find support for this conjecture as the effects of both predictors were practically identical.

\section{The Role of Type of Crime and Gender}

The current research employed crime scenarios depicting interpersonal and political-fundamentalist crime that is stereotypically associated with Muslim males. If we had investigated crimes typically associated with high-status groups (e.g., tax 
fraud, embezzlement), the pattern of results might have been different. For example, Gordon, Bindrim, McNicholas, and Walden (1988) demonstrated that AfricanAmerican defendants were more likely than White defendants to be perceived as committing street crime such as burglary, whereas the opposite was true for economic and corporate crime. One could expect that social dominators would be particularly harsh toward ethnic minority members committing low-status street crime and particularly lenient toward majority ingroup members committing highstatus corporate crime, whereas the opposite pattern would emerge for egalitarians.

Moreover, social dominance theory has argued that males rather than females are the primary targets of arbitrary-set discrimination. This so-called subordinate-male target hypothesis (SMTH) has been confirmed in a number of domains ranging from discrimination in the housing and labor markets to discrimination in the criminal justice system (Sidanius \& Pratto, 1999). While our study only examined male defendants and crime typically associated with males, based on the SMTH, one could expect that crime judgments involving subordinate males would be harsher than those involving subordinate females. To the extent that hierarchy regulation is mainly a product of male-on-male competition, one might also suspect that men would be harsher than women in their crime judgments concerning ethic-minority males. However, as a woman was the victim in the rape-crime scenario and as rape can be conceived as a tool for men to control women (Brownmiller, 1975), women should be particularly severe when judging rape. Further research is needed to investigate the role of crime type and gender in hierarchy-regulation motives underlying crime judgments (see also Navarrete, McDonald, Molina, \& Sidanius, in press).

\section{Hierarchy Regulation or Group Protection?}

The findings of this research need to be discussed in light of other theoretical approaches and of prior research that has evidenced that under certain circumstances deviant ingroup members are judged and treated in less favorable ways when compared to deviant outgroup members. Most prominently, the subjective group dynamics model (Marques et al., 2001) has shown the role of ingroup norms in accounting for this effect. Drawing on social identity theory (Tajfel \& Turner, 1979), the subjective group dynamics model argues that to reestablish a positive social identity, derogation of ingroup members becomes likely when important ingroup norms are undermined and when one is highly identified with the ingroup and its norms (see also Branscombe, Wann, Noel, \& Coleman, 1993; Castano, Paladino, Coull, \& Yzerbyt, 2002). The role of ingroup identification is also emphasized in a study by Hutchison, Abrams, Gutierrez, and Viki (2008), who showed that group identification improved ingroup stereotypes following the presentation of an unfavorable ingroup member (see also Castano et al., 2002; Hutchison \& Abrams, 2003). When presented with an unfavorable outgroup member, ingroup identification was associated with a greater shift toward a more negative outgroup stereotype. Arguing that individual rather than group protection takes place when encountering unfavorable ingroup members, Eidelman and Biernat (2003), in turn, demonstrated that group disidentification was an individualistic 
protective motive. Creating distance between oneself and the unfavorable ingroup member weakens the association between the self and the threatening entity (see also Jost et al., 2001).

The concept of right-wing authoritarianism (RWA; Altemeyer, 1998) can also explain the differential crime judgments. As RWA primarily captures social conformity with ingroup norms, one might expect that, similar to high national identification, high RWA would predict harsher reactions to ingroup offenders than to outgroup offenders. However, in an Australian context, high authoritarians judged the penalty of ethnic outgroup members as more deserved and reported more positive affect about the penalty than did low authoritarians (Feather \& Oberdan, 2000; Feather \& Souter, 2002). In contrast, low authoritarians were more lenient toward the Asian outgroup offender than the Anglo-Australian ingroup offender reporting less positive affect about the penalty and judging the offence as more justified when the offender was Asian compared to an Anglo-Australian offender. These findings are in line with the results of the current study suggesting that as low RWA individuals are less willing to categorize themselves and others as ingroup and outgroup members, they are also more motivated to attenuate hierarchic ethnic relations (see also Verkuyten, 2009).

Our studies demonstrated that crime judgments in intergroup contexts, in addition to symbolic affirmation of ingroup norms, maintenance of positive social identity, and enforcement authoritarian rules, are also driven by hierarchy regulation motives (see also Mendoza et al., 2005). More importantly, the current research suggests that hierarchy regulation occurs more consistently in the evaluation of the target group as a whole than in criminal judgments directed merely at individual delinquents (see Kemmelmeier, 2005). Differential evaluation of criminal offenders is therefore a strategy to enhance and to legitimize, or to attenuate and to challenge, the existing social hierarchy.

The finding in which high SDO individuals derogate outgroups to legitimize the existing social hierarchy is also in line with system-justification research showing how psychological needs lead to acceptance of the status quo in the societal hierarchy that benefits the high-status ingroup (Jost et al., 2003, 2004). The response pattern of derogating the ingroup more than the outgroup found among low SDO individuals, in turn, is similar to previous findings among individuals with high ingroup identification. This may appear contradictory because SDO and ethnic identification are frequently positively correlated in dominant groups (Thomsen, Green, Ho, \& Sidanius, in press). As we found scant evidence of the role of national identification, more research is needed to clarify whether these hierarchy-regulating and social-identity motives operate simultaneously when judging criminal acts. One avenue for future research is examining not only the impact of degree of national identification, but also the impact of the content one bestows on this identity (Pehrson, Brown, \& Zagefka, 2009) and how this content interacts with SDO. When individuals conceive their nation as democratic and liberal, both national identification and low SDO should lead to lenient reactions toward low-status ethnic minority offenders. However, when individuals conceive their nation in nationalistic terms, superior to other nations, both national identification and high SDO should lead to harsh reactions toward low-status ethnic minority offenders. 


\section{Conclusion}

In the media, in public opinion and in political discourse, crime is often associated with immigrants. The criminal behavior of immigrants is depicted as more likely, and thus as more threatening and immoral than delinquency among the majority population. In Switzerland, where our studies were conducted, the leading rightwing party capitalized in its most recent election campaign on the immigrant-crime threat association by presenting flawed statistics of high crime rates among foreigners. And in an international survey study, even seemingly non-prejudiced people were ready to deport immigrants when they had committed a crime (Pettigrew \& Meertens, 1995; see also Green, 2007). Hence, transgressions provide a socially acceptable reason to expel immigrants. Our study suggests that the exclusion of immigrants occurs chiefly among those who wish to maintain groupbased social hierarchy, where the dominant majority group holds a more powerful position when compared to minorities. In other words, differential judgments of ingroup and outgroup offenders may play a crucial role in the motivated maintenance of group-based hierarchies in the globalized world of today. Clarifying the immigrant-crime association and its psychological bases may thus be a vital strategy to promote fair treatment of immigrants.

Acknowledgments We are thankful to John Antonakis for statistical advice and to Damien Pelet for his help in conducting Study 2. The first author was funded by a Swiss National Science Foundation grant (81LA-068373).

\section{References}

Aiken, L. S., \& West, S. G. (1991). Multiple regression: Testing and interpreting interactions. Newbury Park, CA: Sage.

Altemeyer, B. (1998). The other "authoritarian personality". In M. P. Zanna (Ed.), Advances in experimental social psychology (Vol. 30, pp. 48-92). New York: Academic Press.

Bagby, R. M., \& Rector, N. A. (1992). Prejudice in a simulated legal context: A further application of social identity theory. European Journal of Social Psychology, 22, 397-406.

Baldus, D. C., Woodworth, G., Zuckerman, D., Weiner, N. A., \& Broffitt, B. (1998). Racial discrimination and the death penalty in the post-Furman era: An empirical and legal overview, with recent finding from Philadelphia. Cornell Law Review, 83, 1638-1770.

Barkan, S. E., \& Cohn, S. F. (1994). Racial prejudice and support for the death penalty by Whites. Journal of Research on Crime and Delinquency, 31, 202-209.

Bourg, S., \& Stock, H. V. (1994). A review of domestic violence arrest statistics in a police department using a pro-arrest policy: Are pro-arrest policies enough? Journal of Family Violence, 9, 177-189.

Branscombe, N. R., Wann, D. L., Noel, J. G., \& Coleman, J. (1993). In-group or out-group extremity: Importance of the threatened social identity. Personality and Social Psychology Bulletin, 19, 381-388.

Brownmiller, S. (1975). Against our will: men, women and rape. New York: Simon \& Schuster.

Campbell, C. P. (1995). Race, myth and the news. Thousand Oaks: Sage.

Castano, E., Paladino, M.-P., Coull, A., \& Yzerbyt, V. Y. (2002). Protecting the ingroup stereotype: Ingroup identification and the management of deviant ingroup members. British Journal of Social Psychology, 41, 365-386.

Currie, E. (1998). Crime and punishment in America. Why the solutions to America's most stubborn social crisis have not worked-and what will. New York: Owl books.

Dambrun, M. (2007). Understanding the relationship between racial prejudice and support for the death penalty: The racist punitive bias hypothesis. Social Justice Research, 20, 228-249. 
Dixon, T. L., \& Linz, D. (2000). Overrepresentation and underrepresentation of African Americans and Latinos as lawbreakers on television news. Journal of Communication, Spring, 131-154.

Dunwoody, P. T., \& Frank, M. L. (1994). Effects of ethnicity on prison sentencing. Psychological Reports, 74, 200.

Eberhardt, J. L., Davies, P. G., Purdie-Vaughns, V. J., \& Johnson, S. L. (2006). Looking deathworthy. Perceived stereotypicality of Black defendants predicts capital-sentencing outcomes. Psychological Science, 17, 383-386.

Echebarria Echabe, A., \& Fernandez Guede, E. (2007). A new measure of anti-Arab prejudice: Reliability and validity evidence. Journal of Applied Social Psychology, 37, 1077-1091.

Eidelman, S., \& Biernat, M. (2003). Derogating black sheep: Individual or group protection? Journal of Experimental Social Psychology, 39, 602-609.

Falomir-Pichastor, J. M., Muñoz-Rojas, D., Invernizzi, F., \& Mugny, G. (2004). Perceived in-group threat as a factor moderating the influence of in-group norms on discrimination against foreigners. European Journal of Social Psychology, 34, 135-153.

Feather, N. T., \& Oberdan, D. (2000). Reactions to penalties for an offence in relation to ethnic identity, responsibility, and authoritarianism. Australian Journal of Psychology, 52, 9-16.

Feather, N. T., \& Souter, J. (2002). Reactions to mandatory sentences in relation to the ethnic identity and criminal history of the offender. Law and Human Behavior, 26, 417-438.

Gordon, R. A., Bindrim, T. A., McNicholas, M. L., \& Walden, T. L. (1988). Perceptions of blue-collar and white-collar crime: The effect of defendant race on simulated juror decisions. Journal of Social Psychology, 128, 191-197.

Green, E. G. T. (2007). Guarding the gates of Europe: A typological analysis of immigration attitudes in 21 European countries. International Journal of Psychology, 42, 365-379.

Green, E. G. T., Staerklé, C., \& Sears, D. O. (2006). Symbolic racism and Whites' attitudes towards punitive and preventive crime policies. Law and Human Behavior, 30, 435-454.

Gross, S. R., \& Mauro, R. (1984). Patterns of death: An analysis of racial disparities in capital sentencing and homicide victimization. Stanford Law Review, 37, 27-153.

Hutchison, P., \& Abrams, D. (2003). Ingroup identification moderates stereotype change in reaction to ingroup deviance. European Journal of Social Psychology, 33, 497-506.

Hutchison, P., Abrams, D., Gutierrez, R., \& Viki, G. T. (2008). Getting rid of the bad ones: The relationship between group identification, deviant derogation, and identity maintenance. Journal of Experimental Social Psychology, 44, 874-881.

Johnson, J. H., Jr., Farrell, W. C., Jr., \& Stoloff, J. A. (2000). African American males in decline: A Los Angeles case study. In L. D. Bobo, M. L. Oliver, J. H. Johnson Jr, \& A. Valenzuela Jr (Eds.), Prismatic metropolis. Inequality in Los Angeles (pp. 315-337). New York: Russell Sage Foundation.

Jost, J. T., Banaji, M. R., \& Nosek, B. A. (2004). A decade of system justification theory: Accumulated evidence of conscious and unconscious bolstering of the status quo. Political Psychology, 25, $881-920$.

Jost, J. T., Burgess, D., \& Mosso, C. O. (2001). Conflicts of legitimation among self, group, and system. In J. T. Jost \& B. Major (Eds.), The psychology of legitimacy (pp. 363-388). Cambridge: Cambridge University Press.

Jost, J. T., Glaser, J., Kruglanski, A. W., \& Sulloway, F. (2003). Political conservatism as motivated social cognition. Psychological Bulletin, 129, 339-375.

Jost, J. T., \& Thompson, E. P. (2000). Group-based dominance and opposition to equality as independent factors of self-esteem, ethnocentrism, and social policy attitudes among African Americans and European Americans. Journal of Experimental Social Psychology, 36, 209-232.

Kemmelmeier, M. (2005). The effects of race and social dominance orientation in simulated juror decision making. Journal of Applied Social Psychology, 35, 1030-1045.

Marques, J. M., Abrams, D., Páez, D., \& Martinez-Taboada, C. (1998). The role of categorization and ingroup norms in judgments of groups and their members. Journal of Personality and Social Psychology, 75, 976-988.

Marques, J. M., Abrams, D., \& Serôdio, R. G. (2001). Being better by being right: Subjective group dynamics and derogation of in-group deviants when generic norms are undermined. Journal of Personality and Social Psychology, 81, 436-447.

Marques, J. M., Robalo, E. M., \& Rocha, S. A. (1992). Ingroup bias and the 'black sheep' effect: Assessing the impact of social identification and perceived variability on group judgments. European Journal of Social Psychology, 22, 331-352. 
Marques, J. M., \& Yzerbyt, V. Y. (1988). The Black Sheep effect: Judgmental extremity towards ingroup members in inter- and intragroup situations. European Journal of Social Psychology, 18, 287-292.

McFarland, S. G., \& Adelson, S. (1996, July). An omnibus study of personality, values and prejudice. Paper presented at the annual convention of the International Society for Political Psychology, Vancouver, BC.

Mendelberg, T. (2001). The race card: Campaign strategy, implicit measures, and the norm of equality. Princeton, NJ: Princeton University Press.

Mendoza, R., Páez, D., Marques, J., Techio, E.-M., \& Espinosa, A. (2005). Subjective social control and cultural values: A cross-cultural experimental study on the black-sheep effect and a field study about M-11 [abstract]. Revista de Psicologia Social, 20, 289-300.

Navarrete, C. D., McDonald, M. M., Molina, L. E., \& Sidanius, J. Prejudice at the nexus of race and gender: An outgroup male target hypothesis. Journal of Personality and Social Psychology (in press).

OECD. (2007). Education at a glance. Retrieved June 21, 2008, from http://oecd.org/edu/eag2007.

Oswald, D. L. (2005). Understanding anti-Arab reactions post-9/11: The role of threats, social categories, and personal ideologies. Journal of Applied Social Psychology, 35, 1775-1799.

Peffley, M., \& Hurwitz, J. (2002). The racial components of "race-neutral" crime policy attitudes. Political Psychology, 23, 59-75.

Peffley, M., Hurwitz, J., \& Sniderman, P. (1997). Racial stereotypes and whites' political views of blacks in the context of welfare and crime. American Journal of Political Science, 41, 30-60.

Pehrson, S., Brown, R., \& Zagefka, H. (2009). When does national identification lead to the rejection of immigrants? Cross-sectional and longitudinal evidence for the role of essentialist in-group definitions. British Journal of Social Psychology, 48, 61-76.

Perkins, J. E., \& Bourgeois, M. J. (2006). Perceptions of police use of deadly force. Journal of Applied Social Psychology, 36, 161-177.

Persson, A. V., \& Musher-Eizenman, D. R. (2005). College students' attitudes toward Blacks and Arabs following a terrorist attack as a function of varying levels of media exposure. Journal for Applied Social Psychology, 35, 1879-1893.

Pettigrew, T. F., \& Meertens, R. W. (1995). Subtle and blatant prejudice in Western Europe. European Journal of Social Psychology, 25, 57-75.

Pratto, F., Sidanius, J., \& Levin, S. (2006). Social dominance theory and the dynamics of intergroup relations: Taking stock and looking forward. European Review of Social Psychology, 17, 271-320.

Pratto, F., Sidanius, J., Stallworth, L. M., \& Malle, B. F. (1994). Social dominance orientation: A personality variable predicting social and political attitudes. Journal of Personality and Social Psychology, 67, 741-763.

Said, E. W. (1978). Orientalism. Western conceptions of the Orient. London: Penguin Books.

Shaheen, J. G. (2003). Reel bad Arabs: How Hollywood vilifies a people. The ANNALS of the American Academy of Political and Social Science, 588, 171-193.

Sidanius, J., Levin, S., Rabinowitz, J. L., \& Federico, C. M. (1999). Peering into the jaws of the beast: The integrative dynamics of social identity, symbolic racism, and social dominance. In D. A. Prentice \& D. T. Miller (Eds.), Cultural divides: Understanding and Overcoming Group Conflict (pp. 80-132). New York: Russell Sage Foundation.

Sidanius, J., Liu, J. H., Shaw, J. S., \& Pratto, F. (1994). Social dominance orientation, hierarchy attenuators and hierarchy enhancers: Social dominance theory and the criminal justice system. Journal of Applied Social Psychology, 24, 338-366.

Sidanius, J., Mitchell, M., Haley, H., \& Navarrete, C. D. (2006). Support for harsh criminal sanctions and criminal justice beliefs: A social dominance perspective. Social Justice Research, 19, 433-449.

Sidanius, J., \& Pratto, F. (1999). Social dominance: An intergroup theory of social hierarchy and oppression. New York: Cambridge University Press.

Soss, J., Langbein, L., \& Metelko, A. R. (2003). Why do white Americans support the death penalty? Journal of Politics, 65, 397-421.

Strabac, Z., \& Listhaug, O. (2008). Anti-Muslim prejudice in Europe: A multilevel analysis of survey data from 30 countries. Social Science Research, 37, 268-286.

Tajfel, H., \& Turner, J. C. (1979). An integrative theory of intergroup conflict. In W. G. Austin \& S. Worchel (Eds.), The social psychology of intergroup relations (pp. 33-47). Monterey, CA: Brooks/Cole. 
Thomsen, L., Green, E. G. T., Ho, A. K., \& Sidanius, J. Wolves in sheep's clothing: SDO asymmetrically predicts perceived ethnic victimization among White and Latino students across three years. Personality and Social Psychology Bulletin (in press).

Verkuyten, M. (2009). Support for multiculturalism and minority rights: The role of national identification and out-group threat. Social Justice Research, 22, 31-52.

Wacquant, L. (1999). Les prisons de la misère [Prisons of Poverty]. Paris: Editions Raisons d'Agir.

Wilder, D. A., Simon, A. F., \& Faith, M. (1996). Enhancing the impact of counterstereotypic information: Dispositional attributions for deviance. Journal of Personality and Social Psychology, 71, 276-287.

Young, J. (1999). Exclusive society. London: Sage. 